$\begin{array}{ll}\text { Variants } & \text { Variants } \\ \text { The Journal of the European Society for Textual }\end{array}$

Scholarship

14 | 2019

Varia

\title{
Prolegomena to the New Edition of Francesco da Buti's Commentary on Dante's Commedia. Purgatorio
}

\section{Claudia Tardelli}

\section{(2) OpenEdition \\ Journals}

\section{Electronic version}

URL: http://journals.openedition.org/variants/964

DOI: 10.4000/variants.964

ISSN: 1879-6095

\section{Publisher}

European Society for Textual Scholarship

\section{Printed version}

Number of pages: 95-116

ISSN: 1573-3084

\section{Electronic reference}

Claudia Tardelli, «Prolegomena to the New Edition of Francesco da Buti's Commentary on Dante's Commedia. Purgatorio », Variants [Online], 14 | 2019, Online since 10 July 2019, connection on 12 July 2019. URL : http://journals.openedition.org/variants/964; DOI : 10.4000/variants. 964 


\title{
Prolegomena to the New Edition of da Buti's Commentary on Dante's Commedia: Purgatorio
}

\author{
Claudia Tardelli
}

"Gegen die Kontamination ist kein Kraut gewachsen"

(Maas 1957, 34)

\begin{abstract}
In this article I discuss the relationships between the extant manuscript tradition of Francesco da Buti's commentary on Dante's Purgatorio. My argument shows that the constitutio textus cannot be arrived at in a mechanical way, owing to the numerous contaminations and interpolations. I thus offer some general methodological reflections on how to critically edit a long prose text whose MSS tradition is densely contaminated. With this in mind I make the case that the most appropriate way to approach the making of the edition is to base the text on a single authoritative manuscript.
\end{abstract}

SOON AFTER DANTE'S DEATH IN 1321, the popularity of the Commedia was already so extraordinary in its kind that it generated a need for an exegesis of the poem similar to that which had previously been reserved for Classical authors. ${ }^{1}$ The relevance of Dante's early exegesis to both Dantists and, more generally, scholars of the medieval commentary tradition is not in doubt. Nevertheless, whilst these commentaries contain relevant information, they must be subject to careful interpretation because the textual tradition of each commentary has not always been studied as deeply as it should be and there are problems with the editions, mostly from the nineteenth century, that scholars have to rely on. Over the last two decades, however, enormous effort has been put in resolving this issue and most of the early Dante commentaries can now be read in modern and accurate editions.

The main objective of my new edition of Francesco da Buti's commentary on Dante's Commedia (1385-96), as of all the other Dante commentaries recently pub-

1 I am grateful to Zyg Barański for his enthusiastic response to the new edition project at all stages and for his intellectual generosity. I am also indebted to Fabrizio Franceschini, Simon Gilson, Helena Sanson, Fabrizio Cigni, Elena Pierazzo, Wim Van Mierlo and the anonymous reviewer at Variants for their invaluable and helpful comments.

On the early commentary tradition, see Dionisotti 1965, Mazzoni 1965, Sandkühler 1967, Jenaro-MacLennan 1974, Vallone 1981, Minnis and Scott 1988, pp. 440-58; Hollander 1994, Parker 1997, Barański 2001, Bellomo 2004, Gilson 2005, Franceschini 2008, Malato and Mazzucchi 2011, and Nasti and Rossignoli 2013. 
lished, is to provide a reliable and accurate text, expurgated of errors, equipped with an apparatus which critically justifies the editor's textual choices, and furnished with an apparatus fontium. ${ }^{2}$

This article is thus a preparatory study to the new critical edition, which will soon be published by Salerno Editrice (Rome) as part of the series 'Edizione Nazionale dei Commenti danteschi' in several volumes. The main aim is to investigate the manuscript tradition of the Purgatorio's section of Francesco da Buti's commentary. Since Buti's commentary on the Commedia is a particularly long text (over one million words) it has seemed appropriate to offer separate preparatory studies for each canticle. ${ }^{3}$ After a brief introduction on Buti himself and on the genesis and fortune of his Dante commentary, I intend to discuss in these Prolegomena the relationships between the extant manuscript tradition of the Purgatorio section. In doing so, I will show that the constitutio textus cannot be arrived at in a mechanical way, owing to the numerous contaminations and interpolations. I will thus offer some general methodological reflections on how to critically edit a long prose text whose MSS tradition is contaminated. As a result of this discussion, I will argue that the most appropriate way to approach the making of the edition is to base its text on a single authoritative manuscript (i.c. MS N).

\section{Introduction}

Francesco da Buti (1324?-1406), ${ }^{4}$ born in Pisa, started his career as a Magister at the Studio pisano (the University of Pisa) in 1351 and became a notary in 1352. Twenty years later, he was appointed to the Chair of Latin by Pietro Gambacorta, the Governor of Pisa, at the Studio where he taught classical Latin literature for nearly the rest of his life. ${ }^{5}$ His scholarly production includes an

2 The number of editions that has appeared in the last twenty or so years is impressive. See, for instance, Bellomo 1989; Rossi 1990 and 1998; Pisoni and Bellomo 1998; Chiamenti 2002. See also the edition of the Ottimo (Di Fonzo 2008) whose flaws have been highlighted by Perna 2009. A useful work of reference on the Trecento Dante commentators is Bellomo 2004. For editions within the "Edizione Nazionale" project, see Procaccioli 2001; Mazzucchi 2002; Marzo 2003; Mazzucchi 2004; Abardo 2005; Marcci 2004; Pirovano 2006; Corrado 2007; Volpi 2009; Azzetta 2012; Rinaldi 2013; Boccardo et al. 2018. For information regarding the project itself, see Malato et al. 2008, 32-46. For a complete presentation of the entire manuscript tradition of Dante's commentators, see Malato and Mazzucchi 2011.

3 For the Inferno section, see Tardelli 2014, for the Paradiso, see Tardelli 2018a.

4 The bibliography on Francesco da Buti is vast. See, at least, Mazzoni 1971, Alessio 1981, Banti 1995, Varanini 1995, Tolaini 2002, Costamagna 2003, Basile 2005. Additionally, see the many studies by Franceschini, which have contributed to a better understanding of Buti's biography and his historical context, of the commentary's genesis and of its structure, its linguistic concerns and its ideological dimension, and paved the way to the making of a new modern edition.

5 One of the first initiatives Pietro Gambacorta took when he became overlord of Pisa was to relaunch the University. In December 1370, a committee of Sapientes Viri 
Accessus to Terence's comedies and commentaries on Horace's Ars Poetica, on Persius' Saturae, as well as on Alexander of Villedieu's Doctrinale. Furthermore, between 1355 and 1378, he composed and published the Regule grammaticales, also called the Regule pisane or Notabilia pisana, "the most influential secondary school-level treatise of the fourteenth century" (Black 2013, 262). From 1349 onwards, Francesco took on numerous institutional and civic offices in the Pisan government. In 1365 he became Notary of the Seniors, and in 1369 Chancellor of the Seniors, the secretary and chancellor of the city government. As well as being appointed to the Chair of Latin, he was nominated to several other important offices, among others a second mandate as Chancellor of the Seniors and Official Ambassador to Florence (1397) and to Venice (1398).

In 1385 Buti was commissioned to give a series of public lectures in the Pisan Studium on Dante's Commedia. ${ }^{6}$ The lectures were intended to confer prestige on the Studio, on Signore Pietro Gambacorta, and on the city of Pisa as a whole. They mark a vital moment both in the Pisan cult of Dante and in the history of the poem's critical reception, particularly as regards Pisa's longstanding rivalry with Florence, where no new lectures on Dante had been scheduled since Giovanni Boccaccio's unfinished public reading (October 1373-January 1374). Their publication, sponsored by the Gambacorta family, was of some note, as is attested by the high quality of MS B, exquisitely illuminated, whose text was penned by the family's chaplain, "Iohannes quondam Wilhelmi de Berlandia" (f. 92v).

Francesco da Buti produced two different versions of his Dante commentary (Franceschini 1995, 1998a and 1998b; Tardelli 2010, 20-23; Tardelli 2014, 101 and 2018a, 144-45). The first was completed in June 1394. This version of the text is the basis of the nineteenth century standard edition upon which scholars currently rely. ${ }^{7}$ However, as early as November 1394 Buti started revising the commentary on the Inferno and Paradiso making modifications and corrections, integrating new materials, and adding more citations from ancient authorities. This resulted in the completion of a new version of the commentary, finally released on 22 December 1396 (Franceschini 1998a, 219, and 1998b, 219-21 and n31). Whereas the commentary on Purgatorio seems to have been left untouched, both the Inferno and Paradiso present numerous textual changes, the latter being the most densely reworked part (Tardelli 2018a). Regretfully, this version of the commentary, representing the author's latest intention, has so far only been

recommended the appointment of the jurists Pietro del Lante and Piero degli Albizi, the medical doctor Andrea Gittalebraccia and Francesco da Buti as "doctor gramatice" (Archivio di Stato Pisano = ASP, Comune, divisione A, reg. 38, f. 290). See Franceschini, 2011a, 194. For more general information on Gambacorta, see Silva 1911 and Tangheroni 2002.

Thanks to a document discovered by Pietro Silva (ASP, Comune, divisione A, reg. 221, f. 76) we know that Buti's annual salary increased significantly from 55 lire in 1355 to 308 in 1385. Scholars have claimed that this raise was linked to his public lectures on Dante (Silva 1918, 492; Franceschini 2011a, 195).

Giannini, Crescentino, ed. 1858-62, see below: p.99 
accessible in manuscript form as it has never been published before. In order to redress this lacuna, the new edition of Buti's commentary, which I am currently revising for publication, takes into account the author's revisional process by offering the text completed in 1396; a provisional version of the text is already available in Tardelli 2010-11 (Inferno commentary) and Tardelli 2015 (Purgatorio and Paradiso commentaries).

\section{Transmission and Fortune of Buti's Commento}

The commento's text is preserved in twenty-eight manuscripts, all of which have been dated between the fourteenth and fifteenth centuries. Of these only three contain the commentary in their entirety, whereas the others transmit the glosses on one cantica only (of either Inferno, Purgatorio, or Paradiso), or, as in MS L, on two (Purgatorio and Paradiso). This is mainly due to the length of the text, which suggests that more than one copyist was commissioned to undertake its preparation. ${ }^{8}$ Furthermore, the three commentaries met with different degrees of success: not counting the manuscripts containing the complete commenta, the Purgatorio commentary exists in only six copies, whereas those on the Inferno and Paradiso are transmitted in respectively eleven and nine manuscripts.

The manuscript tradition indicates that between the end of the fourteenth and the beginning of the fifteenth centuries the commentary was well received in the whole of Tuscany. For instance, prestigious copies, exquisitely illuminated, were produced within the Pisa-Lucca area, such as the three MSS containing the commentary as a whole: MS B, commissioned by the Gambacorta family, was penned, up to Purgatorio 11, by their own chaplain, Johannes of Berlandia, in early 1390s; MS M, written in Lucchese vernacular, was owned by the Guinigi family from Lucca; and finally MS N, particularly important not only for being entirely written in Pisan vernacular, but also for transmitting the revised version of the commentary released in 1396. Across the region, many famous figures, such as Cione da Ravi of Maremma, owned a copy of the commento; intellectuals and members of the Florentine Academy, such as Vincenzo Borghini and Piero del Nero; Crusca Academy members, such as Pietro Segni "l'Agghiacciato" and Gianbattista Deti "il Sollo", Antonio de' Medici and members of the de' Bardi family; Dante scholars such as Filippo Villani, lector in Florence, Bartolomeo Nerucci da San Gimignano, lecturer in Prato (Franceschini 1995, 100; 2013, 73-75). Moreover, the interest in Buti's commento within religious circles is confirmed by fra Bartolomeo da Colle, one of the most famous preachers of the fourteenth

8 For instance, MSS Riccardiani 1006, 1007 (R2) and 1008 were edited as part of the same editorial project, as well as MSS Milan, Biblioteca Nazionale Braidense AF XI 31 and 32 (MB'), together with Florence, Biblioteca Nazionale Centrale, Conv. Soppr. J III 4 (Paradiso). MSS Florence, Biblioteca Medicea Laurenziana, Plutei 42.14 (Inferno), 42.15 (L2), 42.16 (Paradiso), written by Bartolomeo Nerucci da San Gimignano for his lectura Dantis in Prato, also belong to the same editorial project (Bellomo 2004, 250; Franceschini 2011a, 203). On Nerucci as reader of Dante, see Franceschini 2011b and 2013, 73-75. 
century, who decided to include Buti's glosses in his own copies of the Commedia (Franceschini 2013, 83-88). Interestingly, the MSS tradition is also composed of several copies whose features point to their having belonged to notarial and mercantile circles rather than professional ones (Pomaro 2003, 317-19). This shows that curiosity in Buti's commentary was broad and not just limited to intellectual, political, and religious circles.

Nevertheless, Buti's commento had little influence outside Tuscany; the vernaculars used in the MSS are all from the Tuscany region, which suggests its reach elsewhere was limited. ${ }^{9}$ Florence was the most receptive to Francesco's work. The commentary met with very early success within the erudite circle of Santa Croce, where, as early as 1394, one of the first copies of the Inferno commentary was completed in a manuscript penned by a particularly intelligent and active scriba (MS Città del Vaticano, Bibl. Apostolica Vaticana, Vat. Lat. 1728). The commentary's popularity in the Florence area is also confirmed by the influence of Francesco's commentary on Filippo Villani's work (Bellomo 2004, 387). The texts preserved in MSS Florence, Bibl. Medicea Laurenziana, Plutei 42.14, 42.15 (L2) and 42.16, and edited by Bartolomeo Nerucci da San Gimignano between 1431 and 1434, confirm the success it enjoyed particularly among students of grammar during the first half of the fifteenth century. Among humanists, Francesco's chiose were used extensively by Cristoforo Landino while writing his Comento, which was first published in Florence in 1481 by Niccolò di Lorenzo della Magna, as Barbi's research showed in $1890(1975,146-79)$ and, more recently, that of Procaccioli (1989, 143-254), and Gilson (2005, 194-98; 213-28).

During the fifteenth century, Francesco da Buti was thus one of the best-known and most highly regarded Dante commentators, especially in the Florence area. However, despite these successes Buti's commentary was gradually supplanted by Landino's Comento and, although it was copied during the following centuries within erudite circles (Franceschini 2011a, 204), it was not printed in its entirety until the mid-nineteenth century, when it was edited by Crescentino Giannini (1858-62) and published in Pisa by the Nistri brothers. This is still the current standard edition.

Giannini's edition is based on MSS Riccardiani 1006, 1007 (R2) and 1008, since the editor believed them to be "i codici più reputati esistenti nelle publiche Biblioteche di Firenze" ("the most authoritative manuscripts available in Florence public libraries") (Giannini 1858-62, 1: viii). These manuscripts were chosen based on the fact that they had been considered written in good Florentine by members of the Crusca Academy (Giannini 1858-62, 1: viii). Established in Florence in 1583, the Academy's main aim was to preserve the beauty of the Florentine vernacular that was modelled upon the authors of the Trecento. Giannini's MSS choice effectively highlights one of the main problems regarding his text: its language; for the editor believed it was preferable to base his edition upon Florentine MSS rather than Pisan. In particular, Giannini's text, for the

9 MS Città del Vaticano, Bibl. Apostolica Vaticana, Rossiano 1069, (Inferno), is the only text demonstrating linguistic traits from the North of Italy. 
most part, presents the phono-morphological and lexical characteristics of the Florentine vernacular rather than of Pisan, and thus departs from the author's original language. Moreover, as briefly mentioned, the editor made Buti's first version of the text available to the readers, i.e. the one released in 1394, rather than the last, completed in 1396.

\section{The Manuscript Tradition of Buti's Commentary on Purgatorio}

The extant manuscript tradition of Buti's commentary is not the richest among Dante commentaries. ${ }^{10}$ However, Buti's commento is one of, if not actually, the longest (over one million-words) of all commentaries, which constitutes a considerable problem for the scholarly editor. The situation is further complicated by the fact that especially prose commentaries were written without strict formal constraints, which allowed modification, rewriting, re-arrangement, and the addition of new material. This phenomenon reflects the concept of "mouvance" of medieval texts described by Zumthor in relation to medieval French poetry in which vernacular works could be indefinitely reworked by several authors and pass through a series of different "états du texte" $(1972,72)$. Not surprisingly, and in keeping with the results previously obtained for the Inferno (Tardelli 2014) and Paradiso (Tardelli 2018a), it has not been possible to group the Purgatorio manuscripts in Lachmannian terms or reconstruct the author's original text on account of contaminations and interpolations. Additionally, any conventional attempt at arriving at a restitutio textus is further complicated by the likely presence of a "originale in movimento", which makes a Lachmannian approach to Buti's text anachronistic and, to some extent, counter-productive. ${ }^{11}$ Therefore, after a thorough investigation of the MSS tradition, I have decided to base the edition on a single authoritative manuscript, according to the fundamental methodological principle suggested by Luca Carlo Rossi for editions of Dante's oldest commentaries:

Un'edizione tradizionale è forse improponibile. [. . .] La contemperanza di un buon manoscritto base, [ . . .], e di un uso non rigido dello stemma che si è riusciti a tracciare (quando è possibile disegnarlo) offrono, in via di massima, sufficienti garanzie per la costituzione di un testo che sia provvisto di un valore critico o, per lo meno, criticamente tollerabile.

[A traditional Lachmannian edition is perhaps unfeasible [. . .] Working with an authoritative base-text [. . .], together with a stemma codicum (should the editor being able to trace one), may be sufficient to provide a text that has critical value or that is at least rather critically tolerable].

10 The manuscript tradition of Iacomo della Lana's Comento, for instance, is made up of over one hundred copies (Volpi 2008, 269-72).

11 On the "tradizione orizzontale" as opposed to the vertical line of descent, see Pasquali 1988, 140-41; on Lachmann's limitations see Reynolds and Wilson 1974, 225-27. 
$(\text { Rossi 2001, 130-31) })^{12}$

The new edition of the Purgatorio text will therefore be based on a single, most authoritative MS, namely MS N. This MS is written in the Pisan vernacular, which is the original language; it transmits the commenta on all three cantiche; and it preserves the second and revised version of the text (Tardelli 2010; 2014; 2018a). No systematic philological study has ever been undertaken of the extant MSS tradition. The following pages offer the results of my exploration and findings, together with a discussion of the most significant errors and variant readings. A traditional word-by-word collation was carried out for the Proemio and the first two canti, thereby allowing me comprehensively to assess the dynamics of at least two complete cantos. Loci selecti have subsequently been identified and compared in the extant manuscript tradition from Purgatorio 3 onwards. ${ }^{13}$

From this investigation, I was able to identify two groups of MSS: the first, which I term $\alpha$, is composed of $\mathrm{N}, \mathrm{L} 2, \mathrm{MB}^{\prime}$ and R4; the second, which I designate $\beta$, is composed of $B, M, C,{ }^{14} L$, and $R 2$. Nevertheless, it is very important to note that the grouping outlined above does not consistently occur on account of conflation and contamination, as already noted. Consequently, the data reported in the tables below are not representative of a systematic pattern in the relationship of the manuscript tradition, but only reflect a tendency. However, in the table of errors below I demonstrate that it is possible to postulate the agroup (N, L2, MB', R4) by considering the following common errors: ${ }^{15}$

\begin{tabular}{l|l|l}
\hline & $\alpha$-group & $\beta$-group \\
\hline $2.25-36$ & om.* & $\begin{array}{l}\text { che le ginocchia cali, cioè che } \\
\text { tt'inginocchi. Ecco l'angel di } \\
\text { Dio, ecco che llie manifesta, } \\
\text { piega le mani [. . . ] }\end{array}$
\end{tabular}

12 The application of the same principles has been supported by Bellomo 2001, 26.

13 The same criteria were applied to the new edition of the Inferno (Tardelli 2010-11) and Paradiso (Tardelli 2015). Loci selecti are as follows: 3.Intro; 3.1-9; 3.10-21; 3.22-33; $3.34-45 ; 3.46-60 ; 3.61-72 ; 3.79-93 ; 3.103-17$; 3.118-32; 3.133-41; 4.1-18; 4.31-39; 4.58-76; $4.76-87 ; 20.85-96 ; 21.103-11 ; 21.103-11 ; 22.64-93 ; 25.31-60 ; 28.103-20 ; 29.82-96$.

14 MS C, in relation to canti 1-4, presents numerous variae lectiones in the margins. A detailed study as well as a separate edition of these unpublished lectiones, which I believe are not authorial, is in progress.

15 Only some of the most significant common errors are noted in the table.

* Both R4 and MB' have "eccho l'angiel di Dio". 


\begin{tabular}{|c|c|c|}
\hline & $\alpha$-group & $\beta$-group \\
\hline 3. Intro. & $\begin{array}{l}\text { prima pone come pervenne } \\
\text { ad Roma }^{\dagger} \text { al monte }\end{array}$ & $\begin{array}{l}\text { prima pone come pervenne } \\
\text { al monte }\end{array}$ \\
\hline $3.10-21$ & $\begin{array}{l}\text { secondo la lictera, finge } \\
\text { Dante che corresse Virgilio, } \\
\text { et elli dirieto a llui come } \\
\text { l'altre anime correano }{ }^{\ddagger}\end{array}$ & $\begin{array}{l}\text { secondo la lictera, finge } \\
\text { Dante che corresse Virgilio, } \\
\text { et elli dirieto a llui come } \\
\text { l'altre anime corseno }\end{array}$ \\
\hline $3.118-32$ & nel pecto sommo del pecto p $^{\S}$ & al sommo del pecto \\
\hline $3.133-41$ & $\begin{array}{l}\text { Ad che debbiamo sapere che } \\
\text { chi è scomunicato dal papa, } \\
\text { o da' suoi vicari, è fuori della } \\
\text { congregatione de' fedeli cris- } \\
\text { tiani, sì che nulla oratione che } \\
\text { si faccia per la Sancta Chiesa } \\
\text { di magior scomunicatione et } \\
\text { per li catolici. TI }\end{array}$ & $\begin{array}{l}\text { Ad che debbiamo sapere che } \\
\text { chi è scomunicato dal papa, } \\
\text { o da' suoi vicari, di magior } \\
\text { scomunicatione è fuori della } \\
\text { congregatione de' fedeli cris- } \\
\text { tiani, sì che nulla oratione che } \\
\text { si faccia per la Sancta Chiesa } \\
\text { et per li catolici. }\end{array}$ \\
\hline $3.133-41$ & $\begin{array}{l}\text { et dopo lo terço dì, avuto } \\
\text { santo Gregorio che questi } \\
\text { era per questo peccato grave- } \\
\text { mente tormentato per revela- } \\
\text { tione, comandò al proposto } \\
\text { che tre "l giorni facesse dire } \\
\text { messe nel monesterio et cel- } \\
\text { ebrare lo divino sacramento } \\
\text { per l'anima di questo monaco. } \\
\text { Facto questo, et infine de' tre" } \\
\text { dì adparve il dicto monaco }\end{array}$ & $\begin{array}{l}\text { et dopo } 30 \text { dì, avuto santo } \\
\text { Gregorio che questi era per } \\
\text { questo peccato gravemente } \\
\text { tormentato per revelatione, } \\
\text { comandò al proposto del } \\
\text { monastero che } 30 \text { giorni } \\
\text { facesse dire messe nel mon- } \\
\text { esterio et celebrare lo divino } \\
\text { sacramento per l'anima di } \\
\text { questo monaco. Facto questo, } \\
\text { et infine de' } 30 \text { dì adparve il } \\
\text { dicto monaco }\end{array}$ \\
\hline
\end{tabular}

\footnotetext{
$+\quad$ Expunged in L2.

$\ddagger \quad$ The relevant folio is missing in R4.

$\S \quad$ Both L2 and MB' try to mend to error: L2 expunged the first "pecto", MB' only transmits "nel pecto".

II L2 adds "di magior scomunicatione" in the upper margin but it also transmits it after "Sancta Chiesa".

\| L2 amends "tre" in "trenta".
} 


\begin{tabular}{|c|c|c|}
\hline & $\alpha$-group & $\beta$-group \\
\hline $4.1-18$ & om. & $\begin{array}{l}\text { la quale pillia et unisce ad } \\
\text { sé la vegetativa et sensitiva, } \\
\text { dando loro perfetione, la } \\
\text { quale non arebbeno da sé. Et } \\
\text { fa questa unione per sì facto } \\
\text { modo ch'ella è cagione del } \\
\text { loro operare et mai non si } \\
\text { disfà questa unione, ma anco } \\
\text { quando si parte l'anima dal } \\
\text { corpo, ne la porta seco benché } \\
\text { non abbino più actività niuna, } \\
\text { et viene l'anima humana } \\
\text { dotata de le infrascripte tre } \\
\text { dote, le quali sono più active } \\
\text { quando è separata dal corpo } \\
\text { che quando è coniunta. Viene } \\
\text { addunqua }\end{array}$ \\
\hline
\end{tabular}

The last case (4.1-18) is representative of the phenomenon of conflation. The part of the text that the $\alpha$-group omits here is in reality also transmitted in $\mathrm{N}$, but in the lower margin, which shows that the copyist was working from two exemplars at the same time.

Furthermore, it can now be assessed that $\mathrm{L} 2, \mathrm{MB}^{\prime}$ and $\mathrm{R} 4$ are not direct copies of $\mathrm{N}$, since $\mathrm{N}$ includes unique errors. It is thus more plausible that these four manuscripts derive from a common (and lost) intermediate source. The $\alpha$-group is also characterised by its many homeoteleuta and palaeographical errors, generally considered as polygenetic errors; these are errors that several copyists could have made independently from one another and they are therefore not useful for the genealogical classification of the manuscripts (Stussi 2001, 100-04; Trovato $2014,55)$. However, the persuasive possibility of considering certain omissions as monogenetic rather than polygenetic errors is explored by Zaccarello (2012, 109-35; see also Reeve 2011, 55-103) who suggests that in some cases these errors ought to be considered ancillary evidence of relationship between MSS, especially when such errors can be systematically documented in all the MSS that are grouped together. The data gathered so far would suggest that N, L2, R4 and $\mathrm{MB}^{\prime}$ all originate from a common ancestor. However, some other findings would indicate that $\mathrm{L} 2, \mathrm{R} 4$ and $\mathrm{MB}^{\prime}$ actually derive from a collateral of $\mathrm{N}$, at least as far as the later part of the copying process was concerned, i.e. from Purgatorio 20 onwards. In fact, another problem that arises when dealing with long prose texts is the possibility that scribes used an exemplar up to a certain point (i.e. 
until it was available) and then worked from a different one. As a result, the resultant version is a "hybrid text" whose relationship to its models is difficult, if not impossible, to establish. The following example usefully illustrate this kind of circumstance:

\begin{tabular}{|c|c|c|}
\hline & $\mathrm{N}(=\beta)$ & $\mathrm{L} 2=\mathrm{R} 4, \mathrm{MB}^{\prime}$ \\
\hline $20.85-96$ & $\begin{array}{l}\text { Et intorno ad ciò } \\
\text { è da sapere che, } \\
\text { essendo papa } \\
\text { Bonifatio viII natio } \\
\text { d'Alagna, ‘nel } 1301 \\
\text { nel papato [. . ] } \\
\text { Et in Alagna et in } \\
\text { Roma rubbonno li } \\
\text { predicti la camera } \\
\text { del papa, per la qual } \\
\text { cosa poi lo dicto } \\
\text { papa visse poi } 4 \\
\text { dì dipo' la presura } \\
\text { sua in Alagna, et da } \\
\text { sua antica infermità } \\
\text { di fianco, strecto } \\
\text { più fortemente che } \\
\text { l'altre volte, forse } \\
\text { per la malagevilessa } \\
\text { che sostenne in } \\
\text { quelli tre dì et tre } \\
\text { nocti che fu ditenuto } \\
\text { ch'era di verno, } \\
\text { finitte la vita sua in } \\
\text { Roma ne la camera } \\
\text { sua }\end{array}$ & $\begin{array}{l}\text { Et fu rubata la camera del papa dalla } \\
\text { gente dell'arme et in Alagna et in Roma. } \\
\text { Et dicesi che in quelli tre dì non prese } \\
\text { altro cibo che uova fresche scaldate in } \\
\text { su uno tésto di bruna ch'elli portava } \\
\text { alla sedia. Et chi dice che stette quelli } \\
\text { tre dì et tre nocti assediato dalla dicta } \\
\text { gente pure nella camera sua et fu lib- } \\
\text { erato perché l'altra parte che non era } \\
\text { nel tractato di quelli d'Alagna si levò } \\
\text { dipo li tre dì et cacciò fuora l'altra parte } \\
\text { e lli Franceschi et quelli della Colonna. } \\
\text { Et liberato se ne venne papa Bonifatio } \\
\text { ad Roma. Et stato } 4 \text { (R4 MB': quaranta) } \\
\text { dì dipo' lo dicto stringimento si morì } \\
\text { strecto dalla passione del fianco che } \\
\text { aveva, ma forse per lo disagio che aveva } \\
\text { sostenuto quando fu sostenuto (assedi- } \\
\text { ato et sostenuto MB') o per malinconia } \\
\text { più stretto che l'altre volte ne morì }\end{array}$ \\
\hline
\end{tabular}

Moreover, my findings indicate the necessity to postulate the $\alpha^{\prime}$ subgroup, composed of $\mathrm{N}$ and $\mathrm{R} 4$, which appears be contaminated at times with $\mathrm{L} 2$, and at other times with $\mathrm{MB}^{\prime}$, as the following mutual errors show: 


\begin{tabular}{l|l|l}
\hline & $\alpha^{\prime}(\mathrm{N}+\mathrm{R} 4)$ & $\mathrm{L} 2, \mathrm{MB}^{\prime}(=\beta)$ \\
\hline $1.7-12$ & dell'amor/dall'amor & dalla morte \\
$1.85-89$ & come lo giunco in terra & $\begin{array}{l}\text { come lo giunco è fondato } \$ \S \text { in } \\
\text { terra }\end{array}$ \\
\hline
\end{tabular}

\begin{tabular}{l|l|l}
\hline & $\alpha^{\prime}+\mathrm{MB}^{\prime}$ & $\mathrm{L} 2(=\beta)$ \\
\hline $3.103-17$ & con Karlo conte di Provença & $\begin{array}{l}\text { con Karlo, fratello del re } \\
\text { Lodovico di Francia duca } \\
\text { d'Angiò et conte di Provença }\end{array}$ \\
$3.103-17$ & $\begin{array}{l}\text { lo sconfisse a campo ove fu } \\
\text { ferito et morto lo re Manfredi }\end{array}$ & $\begin{array}{l}\text { lo sconfisse a Ceparo l'ultimo } \\
\text { dì di ferraio nel 1265, ove fu } \\
\text { ferito et morto lo re Manfredi }\end{array}$ \\
\hline
\end{tabular}

As for the rest of the manuscripts, in the table below, I demonstrate that it is possible to postulate the $\beta$ group (B, M, C, L, R2) by considering the following common errors: ${ }^{16}$

\begin{tabular}{l|l|l}
\hline \multirow{2}{*}{$28-39$} & $\begin{array}{l}\text { Li raggi delle quattro luci sancte, cioè } \\
\text { di quelle quattro stelle che significa- } \\
\text { vano le quattro virtù cardinali III }\end{array}$ & significano le \\
\hline $2.52-66$ & $\begin{array}{l}\text { Dunqua venimmo inansi ad voi un poco, } \\
\text { presso alla levata del sole, per altra } \\
\text { via, perché venimmo per lo 'nferno } \\
\text { et dal centro del Lucifero in su per } \\
\text { lo luogo obscuro et alto, et voi siete } \\
\text { venuti per lo mare }\end{array}$ & vennot \\
\hline
\end{tabular}

§§ L2 innovates: "nasce".

16 However, as already noted, B is the only MS to carry an abbreviated version of the commento on Purgatorio from canto 11 onwards. 
These errors, albeit borderline in palaeographical terms, are considered significant in hypothesizing the $\beta$ group (Zaccarello 2012, 109-35). In one case, the error alters the verbal tense (imperfect/ present), and it also produces a lacuna of the numeral/word "quattro"; in the other, the error alters the verbal person (first/ third plural), making it difficult to believe that the two copyists had produced both errors independently of one another, that is to say, that the two errors are polygenetical. Alongside these mutual errors, it is important to note that the $\beta$ family always shares the same adiaphorous variants.

Furthermore, I was able to trace a few innovations in both L and R2, all limited to Purgatorio $2-4:{ }^{17}$

\begin{tabular}{|c|c|c|}
\hline & $\mathrm{N}$ & L, R2 \\
\hline 2.Intro. & $\begin{array}{l}\text { Et è da notare che l'autore } \\
\text { finge che tucti possano } \\
\text { andare infine al purgato- } \\
\text { rio sì che a niuno è vietato } \\
\text { andare infine quine** }\end{array}$ & $\begin{array}{l}\text { quine, ma tucti si tornano al luogo } \\
\text { suo, infine che ànno compiuto la } \\
\text { sua penitentia della negligentia dell' } \\
\text { aspectare, et chi avesse peccato in } \\
\text { tucte le } 6 \text { specie, dicte di sopra, in } \\
\text { ogni luogo de' dicti } 6 \text { luoghi sta tanto, } \\
\text { che sia purgato quel grado di negli- } \\
\text { gensia. Et questo si dé intendere sec- } \\
\text { ondo la fictione dell'autore, et alle- } \\
\text { goricamente si dé intendere di quelli } \\
\text { del mondo, che tanto di tempo per- } \\
\text { deno, quanto stanno negligenti ad } \\
\text { tornare ad la penitensia, et li scomu- } \\
\text { nicati per ogni uno, } 30 \text { imperò che } \\
\text { perdono, mentre che stanno scomu- } \\
\text { nicati, lo merito della santa chiesa } \\
\text { che è valevile per virtù del sangue di } \\
\text { Cristo venduto } 30 \text { denari, che no ne } \\
\text { partecipano mentre che stanno sco- } \\
\text { municati }\end{array}$ \\
\hline
\end{tabular}

III MS MB' also transmits "significano le".

㧊 L omits the verb.

17 I have also noted a saut du même au même which L and R2 have in common (presa/prese), which is also shared by the agroup (3.103-17) "per questa Gostança venne lo regno di Sicilia allo imperadore Arrigo prima, imperò ch'elli, «presa la dicta Gostansa per donna cavata del monesterio di Palermo ove ella era facta monaca et consecrata, prese> lo regno e Tancredi". The overall data suggest that the error has originated independently in the agroup and in the $\mathrm{L}+\mathrm{R} 2$ subgroup.

** MS C transmits the same reading of $\mathrm{N}$ but with the integration in the left margin. 


\begin{tabular}{|c|c|c|}
\hline & $\mathrm{N}$ & L, R2 \\
\hline $2.1-9$ & $\begin{array}{l}\text { Uscia di Gange, questo Gange } \\
\text { è uno fiume ch'è nel nostro } \\
\text { oriente, grandissimo fiume, } \\
\text { et dice sancto Ysidoro che } \\
\text { la Teologia lo chiama Geon } \\
\text { Physon, et dice ch'esce del } \\
\text { paradiso delitiarum et entra } \\
\text { in mare correndo verso } \\
\text { l'oriente, et però lo chiamano } \\
\text { li autori foce orientale }\end{array}$ & $\begin{array}{l}\text { foce orientale, come Ibero che } \\
\text { è ne la Spagnia, fiume che } \\
\text { corre inverso lo nostro occi- } \\
\text { dente, chiamano foce occiden- } \\
\text { tale }\end{array}$ \\
\hline $2.10-24$ & $\begin{array}{l}\text { et di socto a poco a poco un } \\
\text { altro, biancho, a llui n'uscio, } \\
\text { et questo era la stola biancha } \\
\text { co.lla quale si dipingono li } \\
\text { angeli sì che non si si pare } \\
\text { niuna forma corporale }\end{array}$ & $\begin{array}{l}\text { corporale, se non nel volto. Li } \\
\text { angiuli quanto ad la verità non } \\
\text { ànno alcuna forma corporale } \\
\text { imperò che sono spirito, ma } \\
\text { dipingonsi col volto umano, ad } \\
\text { dimostrare che ànno volontà lib- } \\
\text { era, ma ora è confermata in gra- } \\
\text { tia: et con l'ali, ad significare la } \\
\text { loro leggeressa che subitamente } \\
\text { possano essere dove vuolliano: } \\
\text { et sono due bianche, ad signifi- } \\
\text { care la memoria et lo intellecto } \\
\text { puro che ànno all'amore di Dio } \\
\text { et del Cristo, et la stola bianca, } \\
\text { ad significare che in loro è tucta } \\
\text { nectessa da ogni peccato }\end{array}$ \\
\hline
\end{tabular}

+t This particular variant could also be interpreted as a saut du même au même, which happens when the same word (in this case foce) occurs more than once on the page, and the scribe, after writing it for the first time, brings his eye back to the page at the second occurrence, and so fails to copy the text in between. In this case the variant would not be an innovation transmitted in both $\mathrm{R} 2$ and $\mathrm{L}$, but an error propagated in the rest of the tradition. 


\begin{tabular}{|c|c|c|}
\hline & $\mathrm{N}$ & $\mathrm{L}, \mathrm{R} 2$ \\
\hline $2.25-36$ & $\begin{array}{l}\text { Ecco l'angel di Dio, ecco che } \\
\text { llie manifesta>, piega le mani, } \\
\text { cioè chinale giù addoppiate a } \\
\text { farli reverentia }\end{array}$ & $\begin{array}{l}\text { reverentia duo sono li acti della } \\
\text { riverentia che si rende ad Dio } \\
\text { et ai santi, cioè lo inginoc- } \\
\text { chiare et adiungere le mani, } \\
\text { che significano rimentimento } \\
\text { della affetione et dell'opere ad } \\
\text { colui ad cui lo fano }\end{array}$ \\
\hline $2.106-17$ & $\begin{array}{l}\text { a l'amoroso canto, cioè al canto } \\
\text { che tractava d'amore }\end{array}$ & $\begin{array}{l}\text { amore o vero che era sì pia- } \\
\text { cente che ogni uno facea di sé } \\
\text { inamorare }\end{array}$ \\
\hline $3.22-33$ & impaccia raggio visuale & $\begin{array}{l}\text { impaccia il raggio del superi- } \\
\text { ore cielo lo 'nferiore, sì che } \\
\text { non passi giuso infino alla } \\
\text { terra, sì come si vede che lli } \\
\text { raggi delle stelle fixe et delle } \\
\text { pianete passano giuso et fanno } \\
\text { l'operatione loro. Et anco } \\
\text { si può intendere del raggio } \\
\text { visuale }\end{array}$ \\
\hline $4.31-39$ & opere & $\begin{array}{l}\text { opere. Lo 'ntrare la peniten- } \\
\text { tia à le suoe malagevilesse, } \\
\text { com'è stato dicto di sopra, } \\
\text { ma lo cominciare ad montare } \\
\text { n'à più imperò che dice santo } \\
\text { Agustino: "Angusta via est, } \\
\text { que ducit ad vitam, et tamen } \\
\text { per eam, nisi dilatato corde, } \\
\text { non curritur" }\end{array}$ \\
\hline
\end{tabular}




\begin{tabular}{l|l|l}
\hline 4.58-76 & antartico & $\begin{array}{l}\text { L, R2 } \\
\text { antartico. Dante si merav- } \\
\text { iglava che 'l sole entrava tra } \\
\text { lui et la parte nostra septentri- } \\
\text { onale, et non imaginava che } \\
\text { elli era nell'altro hemisperio } \\
\text { di là da la torrida çona verso } \\
\text { l'antartico, sì che la via del sole } \\
\text { era tra lui et lo nostro polo } \\
\text { artico, et pe rò finge che Vir- } \\
\text { gilio gliel dichiara, dicendo }\end{array}$ \\
\hline ragione & $\begin{array}{l}\text { ragione, sì che per questo dà } \\
\text { ad intendere così la ragione, } \\
\text { che mi fa advedere di quello } \\
\text { che io mi maraviglava, è questa: } \\
\text { che '1 sole tanto va di là da } \\
\text { l'Equatore verso septentrione, } \\
\text { quanto va di là da l'Equatore } \\
\text { verso l'antartico. Poi esce di } \\
\text { questa materia, dicendo }\end{array}$ \\
\hline
\end{tabular}

Having shown the numerous contaminations and interpolations present in the extant manuscript tradition of the Purgatorio it is clear that the constitutio textus cannot be arrived at in a mechanical way. In other words, it is not possible to consistently group the MSS in a Lachmannian way nor to trace a reliable stemma codicum. It is thus appropriate to base the edition on a single authoritative manuscript. The new edition, based on MS N, will hence offer a text which, for the first time, is consistent and uniform in its language as well as in its "lezione". Errors and vagaries of transmission will be amended through the comparison with the rest of the extant manuscript tradition whose significant variants are noted in the apparatus. Moreover, the edition will provide an apparatus fontium filling a longstanding gap in our knowledge of Buti's intellectual background, his scholarly resources, and his modus operandi. ${ }^{18}$ The commentator drew on classical, Medieval Latin and patristic authors, as well as on the contemporary exegetical tradition on Dante's Commedia. In order to better understand the ways in which Buti utilised his sources, it is important to identify as many of these as possible. In fact, one feature of the commentary that continues to require

18 The only comprehensive critical study so far of Buti's sources is Sassetto 1993 whose methodological limitations have been effectively highlighted by Rossi 1993. On Buti's sources, see Tardelli 2013a, 2013b, 2017, 2018b. 
further investigation concerns the relationship between Buti's commentary and the preceding and contemporary exegetical tradition on Dante's Commedia as well as his relationship to classical, Medieval Latin and patristic sources. If Dante is still regarded as one of the greatest authors of the Western canon, it is in part because he had been perceived and treated as an Auctoritas by his very earliest exegetes. Building on the apparatus fontium of my new edition, scholars will soon be able to assess this vital aspect of the commentary, thereby allowing them to evaluate Buti's work with particular regard to the historical and cultural context in which it was composed. 


\section{List of Manuscripts}

\section{Commedia}

\begin{tabular}{|c|c|}
\hline $\mathbf{N}$ & $\begin{array}{l}\text { NAPLES, Biblioteca Nazionale "Vittorio Emanuele III", XIII C 1; parch.; } \\
\text { XV (first two decades); cc. IV + } 313+\mathrm{III}^{\prime} \text {; mm. } 365 \text { x } 260\end{array}$ \\
\hline B & $\begin{array}{l}\text { FlorencE, Biblioteca Medicea Laurenziana, Conventi Soppressi } 204 \\
\text { (olim Badia Fiorentina L- IX); parch.; XIV ex./XV in. (1405 f. 265ra); } \\
\text { cc. IV + } 281+\text { III'; mm. } 398 \text { x } 277\end{array}$ \\
\hline $\mathbf{M}$ & $\begin{array}{l}\text { Florence, Biblioteca Nazionale Centrale, Banco Rari } 39 \text { (olim Fondo } \\
\text { nazionale II I 29; Magl. VII 1232); parch.; XV in.; cc. IV + } 464+\mathrm{II}^{\prime} ; \mathrm{mm} \text {. } \\
355 \text { × } 260\end{array}$ \\
\hline
\end{tabular}

Purgaturio

C Città del Vaticano, Biblioteca Apostolica Vaticana, Chigi L V 168, chart., XIV ex., cc. 334, mm. 220 x 150

L Florence, Biblioteca Medicea Laurenziana, Pluteo 42.18, chart.; XV in.; cc. $\mathrm{I}+337+\mathrm{I}^{\prime} ; \mathrm{mm} .280 \times 210$

L2 Florence, Biblioteca Medicea Laurenziana, Pluteo 42.15; chart., and parch.; 1431; cc. III + $172+$ II'; mm. 295 x 215

MB Milan, Biblioteca Nazionale Braidense, AF XI 32; chart.; XV in.; cc. $192 ;$ mm. $395 \times 285$

R2 Florence, Biblioteca Riccardiana, 1007; parch.; 1413; cC. III + 208 + I'; mm. $375 \times 270$

R4 FloRENCE, Biblioteca Riccardiana, 1015; chart.; XV (second half); cc. I + $170 ;$ mm. $405 \times 265$

NB: The regesto of Buti's MSS was first published in Franceschini 1995, 103-04. An up-to-date description of the Inferno MSS (+ B, N, and M) can be found in Tardelli 2014, 83-91; and of the Paradiso MSS ( ${ }^{\text {nd }}$ redaction) in Tardelli 2018a, 137-42. 


\section{Bibliography}

Abardo, Rudy, ed. 2005. Chiose Palatine (Ms. BNCF Pal. 313). Roma: Salerno Editrice.

Alessio, Gian Carlo. 1981. “'Hec Franciscus de Buiti”'. Italia Medioevale e Umanistica, 24, pp. 64-122.

Azzetta, Luca, ed. 2012. Andrea Lancia, Chiose alla "Commedia" (autografe: Ms. BNFC II I 39, già magl. VII 1229 bis). 3 vols. Roma: Salerno Editrice.

Banti, Ottavio. 1995. "Francesco da Buti civis pisanus". Bollettino Storico Pisano. 64, pp. 1-18.

Barański, Zigmunt Guido. 2001. "Chiosar con altro testo": Leggere Dante nel Trecento. Firenze: Cadmo.

Barbi, Michele. 1975. Dante nel Cinquecento. Roma: Polla.

Basile, Bruno. 2005. "Lo zaffiro d'oriente: da Dante a Buti". Rivista di Studi Danteschi, 5(1), pp. 155-60.

Bellomo, Saverio, ed. 1989. Jacopo Alighieri, Chiose all' Inferno". Padova: Antenore.

2001. "L'Edizione Nazionale dei commenti danteschi". Rivista di Studi Danteschi, 1(1), pp. 9-26.

—. 2004. Dizionario dei commentatori danteschi: L'esegesi della 'Commedia' da Jacopo Alighieri a Nidobeato. Firenze: Olschki.

Black, Robert. 2013. “Teaching Techniques: The Evidence of Manuscript Schoolbooks Produced in Tuscany". In Juanita F. Ruys, John O. Ward and Melanie Hayworth (eds.), The Classics in the Medieval and Renaissance Classroom. The Role of Ancient Texts in the Arts Curriculum as Revealed by Surviving Manuscripts and Early Printed Books. Turnhout: Brepols, pp. 245-66.

Boccardo, Giovanni Battista, et al., eds. 2018. Ottimo Commento alla 'Commedia'. 4 vols. Roma: Salerno Editrice.

Chiamenti, Massimiliano, ed. 2002. Pietro Alighieri, Comentum super poema Comedie Dantis. A Critical Edition of the Third and Final Draft of Pietro Alighieri's Commentary on Dante's 'The Divine Comedy'. Tempe: Arizona Center for Medieval \& Renaissance Studies.

Corrado, Massimiliano, ed. 2007. Vittorio Rossi (Salvatore Frascìno), Commento alla "Divina Commedia". 3 vols. Roma: Salerno Editrice.

Costamagna, Stefania. 2003. "Le osservazioni retoriche nel Commento di Francesco da Buti alla Commedia: terminologia tecnica e fonti". Studi di Lessicografia Italiana, 20, pp. 35-61.

Dionisotti, Carlo. 1965, "Dante nel Quattrocento". In Atti del Congresso Internazionale di Studi Danteschi. 2 vols. Firenze, Sansoni. Vol. 1, pp. 333-78.

Di Fonzo, Claudia, ed. 2008. L'ultima forma dell'Ottimo commento: Chiose sopra la "Comedia" di Dante Alleghieri fiorentino tracte da diversi ghiosatori: Inferno. Ravenna: Longo.

Franceschini, Fabrizio. 1995. "Il commento dantesco del Buti nel tardo Trecento 
e nel Quattrocento: tradizione del testo, lingua, società". Bollettino Storico Pisano, 64, pp. 45-114.

_. 1998a. "La prima stesura del commento del Buti al Paradiso in un codice appartenuto agli Appiani. Well 1036-Piac 544". Nuova Rivista di Letteratura Italiana, 1, 1, pp. 209-44.

—. 1998b. Dante, il Buti e gli Appiani: Un codice tra Piombino, Piacenza e il Massachussets. Pisa: ETS.

—. 2008. Tra secolare commento e storia della lingua: Studi sulla 'Commedia' e le antiche glosse. Firenze: Cesati.

—. 2011a. "Francesco da Buti". In Enrico Malato and Andrea Mazzucchi (eds.), Vol 1 of Censimento dei commenti dantesch: 1. I commenti di tradizione manoscritta. fino al 1480. Roma: Salerno Editrice, pp. 192-218.

—. 2011b. "Bartolomeo Nerucci". In Enrico Malato and Andrea Mazzucchi (eds.), Vol 1 of Censimento dei commenti dantesch: 1. I commenti di tradizione manoscritta. fino al 1480. Roma: Salerno Editrice, pp, 74-85.

—. 2013. "Grammatici e cultori di Dante tra Volterra, San Gimignano e Colle (Secc. XIV-XV)". Miscellanea Storica della Valdelsa, a. 119, 1-2, pp. 63-92.

—. 2016. "L'Alto Arrigo' e 1"Alto Henrico' nella tradizione del poema e negli antichi commenti". In Giuseppe Petralia and Marco Santagata (eds.), Enrico VII, Dante e Pisa, a 700 anni dalla morte dell'imperatore e dalla "Monarchia" (1313-2013). Ravenna: Longo, pp. 261-87.

Giannini, Crescentino, ed. 1858-62. Commento di Francesco da Buti sopra la 'Divina Commedia' di Dante Allighieri. 3 vols. Pisa: Nistri. Repr. 1989.

Gilson, Simon. 2005. Dante and Renaissance Florence. Cambridge: Cambridge University Press.

Hollander, Robert. 1994. "Dante and His Commentators". In Rachel Jacoff (ed.), A Cambridge Companion to Dante. Cambridge: Cambridge University Press, pp. 226-36.

Maas, Paul. 1957. Textkritik. $3^{\text {rd }}$ ed. Leipzig: Teubner.

Malato, Enrico, et al., eds. 2008. Centro Pio Rajna. Centro di studi per la ricerca letteraria, linguistica e filologica. Vent'anni: 1988-2008. Roma: Salerno Editrice.

Malato, Enrico and Andrea Mazzucchi, eds. 2011. Censimento dei commenti danteschi. 1. I commenti di tradizione manoscritta. fino al 1480. 2 vols. Roma: Salerno Editrice.

Marucci, Valerio, ed. 2004. Niccolò Tommaseo, Commento alla 'Commedia'. 3 vols. Roma: Salerno Editrice.

Marzo, Antonio, ed. 2003. Antonio Cesari, Bellezze della 'Commedia' di Dante Alighieri. 3 vols. Roma: Salerno Editrice.

Mazzoni, Francesco. 1965. "La critica dantesca del secolo XIV". Cultura e scuola, 4, pp. 285-97.

—. 1971. "Francesco da Buti". In Umberto Bosco (ed.), Enciclopedia Dantesca. 6 vols. Roma: Istituto della Enciclopedia Italiana, 1970-78. Vol. 3, pp. 23-27.

Mazzucchi, Andrea, ed. 2002. Chiose Filippine (Ms. Bibl. Oratoriana dei 
Girolamini, Naples, CF 2 16, già 4 20). 2 vols. Roma: Salerno Editrice. , ed. 2004. Matteo Chiromono, Chiose alla "Commedia". 2 vols. Roma:

Salerno Editrice.

Minnis, Alastair, and Brian Scott, eds. 1988. Medieval Literary Theory and Criticism c. 1100-1375. Oxford: Clarendon Press.

Nasti, Paola, and Claudia Rossignoli, eds. 2013. Interpreting Dante, Historicizing

Exegesis: Essays on the Tradition of Dante Commentary. Notre Dame, IN:

University of Notre Dame Press.

Parker, Deborah. 1997. "Interpreting the Commentary Tradition to the Comedy".

In Amilcare Iannucci (ed.), Dante: Contemporary Perspectives. Toronto:

Toronto University Press, pp. 240-58.

Pasquali, Giorgio. 1988. Storia della tradizione e critica del testo. Rev. ed. Firenze: Le Lettere.

Perna, Ciro. 2009. "Recensione" on Di Fonzo, ed., 2008. Rivista di Studi

Danteschi, 9(1), pp. 171-76.

Pirovano, Donato, ed. 2006. Alessandro Vellutello, La "Comedia" di Dante Aligieri con la nova esposizione. 3 vols. Roma: Salerno Editrice.

Pisoni, Pier Giacomo and Saverio Bellomo. eds. 1998. Guglielmo Maramauro, Expositione sopra l' Inferno" di Dante Alligieri. Padova: Antenore.

Pomaro, Gabriella. 2003. "Forme editoriali nella Commedia". In Intorno al testo: Tipologie del corredo esegetico e soluzioni editoriali. Atti del Convegno di Urbino, 1-3 October 2001. Roma: Salerno Editrice, pp. 283-319.

Procaccioli, Paolo. 1989. Filologia ed esegesi dantesca nel Quattrocento: L'“Inferno" nel Comento sopra la "Comedia" di Cristoforo Landino. Firenze: Olschki.

—-, ed. 2001. Cristoforo Landino, Comento sopra la "Comedia". 4 vols. Roma: Salerno Editrice.

Reeve, Michael D. 2011. Manuscripts and Methods: Essays on Editing and Transmission. Roma: Bulzoni.

Reynolds, Leighton D. and Nigel G. Wilson, eds. 1974. Scribes and Scholars: A Guide to the Transmission of Greek and Latin Literature. $2^{\text {nd }}$ ed. Oxford: Clarendon Press.

Rinaldi, Michele, ed. 2013. Guido da Pisa, Expositiones et Glose: Declaratio super "Comediam" Dantis. 2 vols. Roma: Salerno Editrice.

Rossi, Luca Carlo, ed. 1990. Le Chiose ambrosiane alla "Commedia". Pisa: Scuola Normale Superiore.

—. 1993. "Recensione" on Sassetto 1993. Medioevo Romanzo, 18, pp. 447-57.

— - ed. 1998. Graziolo Bambaglioli, Commento all' Inferno" di Dante. Pisa: Scuola Normale Superiore.

—. 2001. "Problemi filologici dei commenti antichi a Dante". Acme, 54, 3, pp. $113-40$.

Sandkühler, Bruno. 1967. Die frühen Dantekommentare und ihr Verhältnis zur mittelalterlichen Kommentartradition. Munich: Hueber.

Sassetto, Francesco. 1993. La biblioteca di Francesco da Buti interprete di Dante: Modelli critici di un lettore della "Commedia" dell'ultimo Trecento. Venezia: Il 
Cardo.

Silva, Pietro. 1911. Il governo di Pietro Gambacorta in Pisa e le sue relazioni col resto della Toscana e coi Visconti. Pisa: Nistri.

__. 1918. "Lo Studio pisano e l'insegnamento della grammatica nella seconda metà del sec. XIV". In Raccolta di studi di storia e critica letteraria dedicata a Francesco Flamini da' suoi discepoli. Pisa: Mariotti, pp. 475-93.

Stussi, Alfredo. 2001. Introduzione agli studi di filologia italiana. Bologna: il Mulino.

Tangheroni, Marco. 2002. Politica, commercio, agricoltura a Pisa nel Trecento. Pisa: Edizioni Plus.

Tardelli, Claudia. 2010. "Per una nuova edizione del commento di Francesco da Buti all'Inferno: Note sulla lezione del MS. Napoletano XIII C 1 e su alcune interpretazioni di passi danteschi nella tradizione manoscritta". The Italianist, 30(1), pp. 18-37.

. 2010-11. Il "Commento" di Francesco da Buti alla "Commedia": Inferno", Nuova edizione. 2 vols. PhD, Scuola Normale Superiore, Pisa.

—_. 2013a. "Tipologie compositive, cultura grammaticale e hapax nel Commento alla Commedia di Francesco da Buti". In Paola Nasti and Claudia Rossignoli (eds.), Interpreting Dante, Historicizing Exegesis: Essays on the Tradition of Dante Commentary. Notre Dame, IN: University of Notre Dame Press, pp. 283-327.

2013b. "Sternulegio". Lingua Nostra, 79, 3-4, pp. 70-74.

2014. "Prolegomena all'edizione del Commento alla Commedia di Francesco da Buti: Inferno". Le Tre Corone, 1, pp. 83-129.

—. 2015. Francesco da Buti's commentary on Dante's "Commedia": New critical edition, based on MS Nap. XIII C 1 "Purgatorio", "Paradiso". PhD, University of Cambridge.

—. 2017. "Reading Aristotle Through Dante: The Case of Meteorologica in Francesco da Buti's Commento". Medium Ævum, 86(2), pp. 350-64.

— 2018a. "Prolegomena to Francesco da Buti's Commentary on Dante's Commedia: Paradiso (1396 version)". Le Tre Corone, 5, pp. 137-66.

—. 2018b. "Dante's la bella figlia as Circe: A Boethian Echo in Buti's Unpublished Gloss on Paradiso XXVII, 137". Italian Studies, 73(1), pp. 22-34.

Tolaini, Emilio. 2002. "Lo specchio dell'Inferno. Un passo dell'Aretino e una nota di Francesco da Buti". Critica d'arte, 16, pp. 34-42.

Trovato, Paolo. 2014. Everything You Always Wanted to Know about Lachmann's Method: A Non-Standard Handbook of Genealogical Textual Criticism in the Age of Post-Structuralism, Cladistic, and Copy-Text. Padua: Libreria Universitaria.

Vallone, Aldo. 1981. Storia della critica dantesca dal XIV al XX secolo. 2 vols. Milano: Vallardi.

Varanini, Giorgio. 1995. "Per Francesco da Buti e il suo commento dantesco". Bollettino Storico Pisano, 64, pp. 19-43.

Volpi, Mirko. 2008. "Per l'edizione del Commento alla Commedia di Iacomo della Lana". Rivista di Studi Danteschi, 8(2), pp. 269-327. 
—. ed. 2009. Iacomo della Lana, Commento alla 'Commedia', con la collaborazione di Arianna Terzi. 4 vols. Roma: Salerno Editrice.

Zaccarello, Michelangelo. 2012. Alcune questioni di metodo nella critica dei testi volgari. Verona: Fiorini.

Zumthor, Paul. 1972. “Le poète et le texte". In Essai de poétique médiévale. Paris: Seuil, pp. 64-106. 